\title{
Erosion of Professional Integrity: The Collapse of the Canterbury TV Building in Christchurch on 22 February 2011
}

\subsection{Characteristics of the Case}

Starting on 4 September 2010, a series of major earthquakes shattered New Zealand for more than one year. Four more significant earthquakes occurred on 25 December 2010, 22 February 2011, 13 June and 23 December 2011. The earthquake of 22 February 2011 was by far the most disastrous, claiming the lives of 185 people. Unlike the two previous earthquakes, the one of 22 February 2011 occurred in the middle of an urban agglomeration, Christchurch, the country's second largest city. Many buildings collapsed due to the earthquake with the magnitude of 6.2 on the Richter scale. The highest death tolls resulted from the collapse of two office buildings, the Canterbury Television (CTV) and the Pyne Gould Corporation (PGC) building. The collapse of the CTV building alone claimed the lives of 115 people or almost two-thirds of the total death toll. A Royal Commission was established on 11 April 2011 to inquire into building failure caused by the Canterbury earthquakes which submitted its reports in several portions starting on 29 June 2012. Volume 6 of the final report of the Royal Commission was devoted to the collapse of the Canterbury Television (CTV) building. ${ }^{1}$ A separate investigation report was commissioned by the New Zealand Department of Building

${ }^{1}$ Canterbury Earthquake Royal Commission. Final Report. 7 Volumes. Wellington, 29 June 2012. Volume 6: Canterbury Television Building (CTV), henceforth quoted as Royal Commission Vol. 6, page number.

W. Seibel, Collapsing Structures and Public Mismanagement, https://doi.org/10.1007/978-3-030-67818-0_4 
and Housing. That investigation was conducted by two engineering corporations, Hyland Fatigue and Earthquake Engineering (HCL) and Structure Smith Consulting Engineers (SSL). ${ }^{2}$

The results of both inquiries left no doubt that fundamental design errors due to incorrect calculations by the chief designer of the CTV building were the root cause of the collapse of 22 February 2011. Although, according to the relevant terms of reference, the Royal Commission did not inquire into any questions of liability it underlined that it did inquire into "errors or failings in design, permitting, construction, inspection or any other matter that might explain why the CTV building failed severely and why its failure caused such extensive injury and death". ${ }^{3}$ That included the failure of public authorities to supervise and to control properly the processes of designing, construction and inspection.

Accordingly, the report of the Royal Commission pertained to three main phases: The history of the CTV building before the first earthquake of 4 September 2010; the status and performance of the building in the September earthquake itself and in the subsequent earthquake of 25 December 2010; an assessment of the condition of the building after those two earthquakes and, finally, the collapse of 22 February 2011 and the immediate trigger factors.

In what follows, the emphasis is laid on the first two of those phases and on a part of the third phase as far as the assessment of the condition of the CTV building after the first earthquake of 4 September 2010 is concerned. It was primarily in the first two phases that public authorities failed to perform properly licensing, permitting and controlling the design, the construction and the overall safety of the CTV building. Unlike the report of the Royal Commission, the HCL \& SSL report focused exclusively on structural engineering issues of the CTV building. It is nonetheless helpful for understanding particular intricacies of the relevant design errors and their consequences under the impact of the three earthquakes of 4 September and 25 December 2010 and the one of 22 February 2011 (Illustration 4.1).

\footnotetext{
${ }^{2}$ Clark Hyland and Ashley Smith: CTV building collapse investigation for Department of Building and Housing: 25 January 2012. Wellington, New Zealand: Department of Building and Housing, henceforth quoted as HCL \& SSL Report, page number.

${ }^{3}$ Royal Commission Vol. 6, 38 .
} 


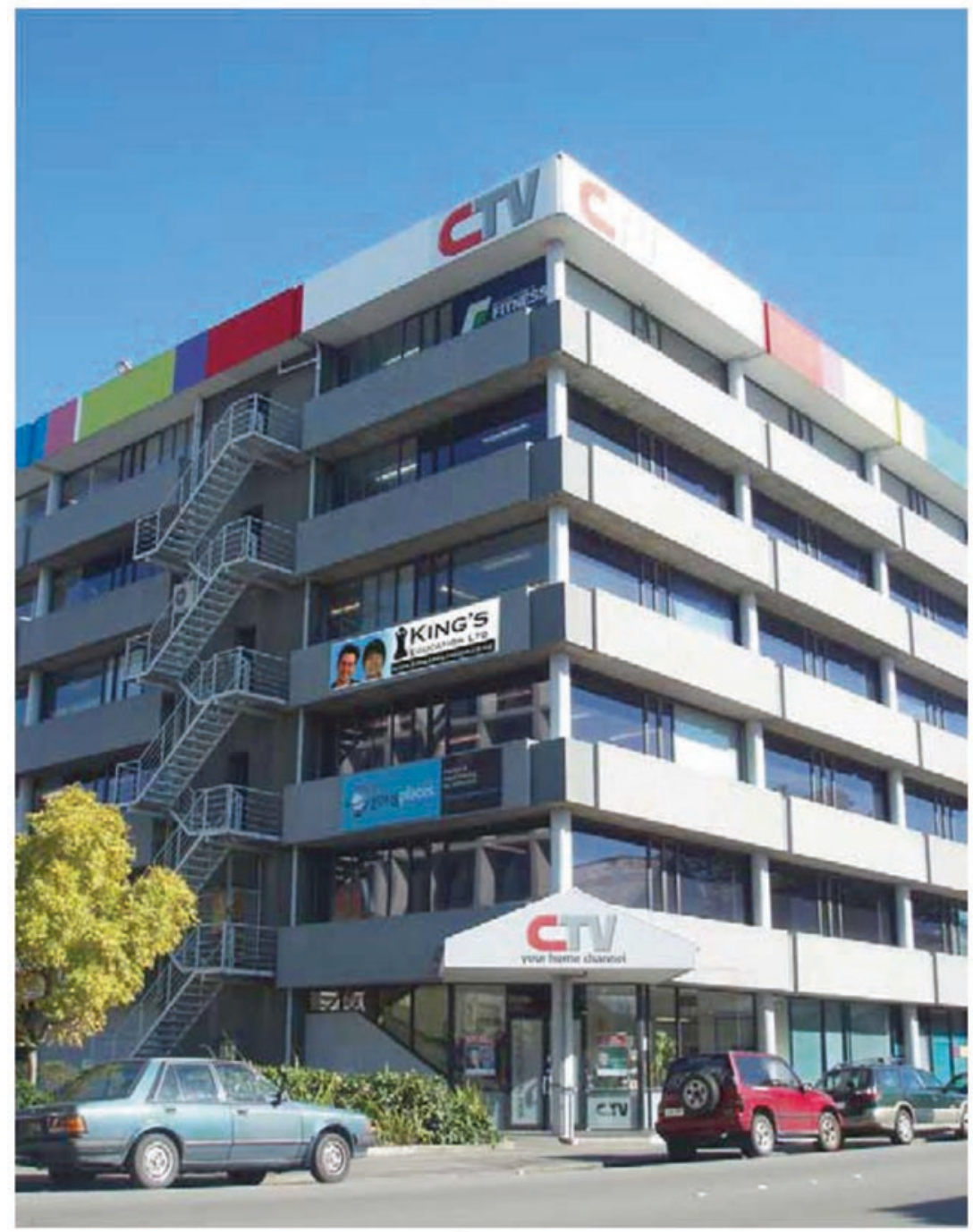

Illustration 4.1 CTV Building Christchurch prior to its collapse on 22 February 2011. (Source: Royal Commission Vol. 6, p. 3) 


\subsection{Facts of the Matter}

The CTV building in downtown Christchurch was of modest height, comprising six stories. Part of the ground level or level 1 was an internal parking structure. The rest of level 1 and the entire level 2 was occupied by Canterbury Television (CTV), a community broadcasting station, hence the name of the building in colloquial language. Level 3 was left vacant. The tenant of level 4 was a private school named King's Education, mainly a language school for international students. On level 5 a medical center was accommodated after its previous domicile had been declared unsafe as a consequence of the earthquake of 25 December 2010. Part of level 6 was occupied by a family and relationship counseling institution named Relationship Services. Students of the language school on level 4 accounted for the majority of those killed on 22 February 2011.

The CTV building had to be designed in accordance with earthquake protection regulation and related professional standards. The building had two main seismic resisting elements, a particular complex or buffer zone at the north side of the building and a shear wall on the South of the building. Columns supported the floors while precast coupling beams connected the floors to the south shear wall and the north wall complex (Illustration 4.2).

Planning of what later became known as the CTV building started in 1986, initiated by the then owner of the premises, Prime West Corporation Ltd. On behalf of Prime West, William Construction Ltd. drafted a proposal to design and build a commercial building on the site in question. On behalf of William Construction Ltd., the architects Alun Wilkie Associates in corporation with Alan M. Reay Consulting Engineer (ARCE) assumed the task to carry out the architectural planning and the structural design of the building. Reay was characterized in the hearings of the Royal Commission as a "very prominent" and award-winning designer of impeccable reputation. ${ }^{4}$ Immediately in charge of the structural design portion of these preparatory works though was David Harding who was employed by ARCE as an engineer. As the Royal Commission found out, Harding, in the process of calculating the structural design of the building, used a computer program at the University of Canterbury with which he was not familiar so that, according to the commission, "he was unaware of some of

\footnotetext{
${ }^{4}$ Royal Commission Vol. 6, 48 .
} 


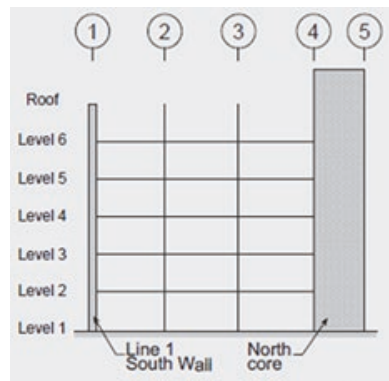

(1)

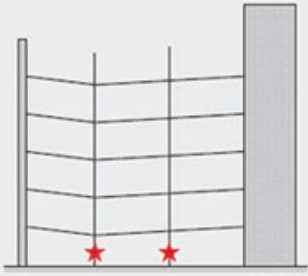

(2)

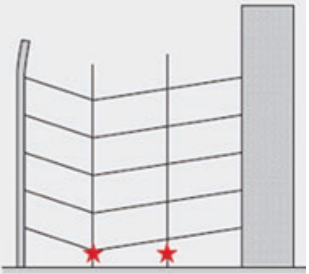

(3)

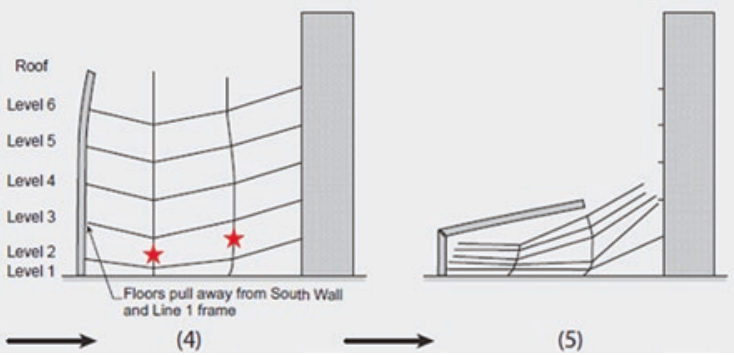

Illustration 4.2 Most likely collapse scenario of the CTV Building with disconnecting floors/diaphragms. (Source: Royal Commission Vol. 6, p. 236 (originally: C. Hyland C. A. Smith, CTV building collapse investigation for Department of Building and Housing: 25 January 2012. Wellington, New Zealand: Department of Building and Housing))

the program's important limitations". ${ }^{5}$ Moreover, prior to assuming the task of developing the structural design of the future CTV building, Harding had never designed a multi-story building with characteristic design features relevant in the case of the CTV. He nonetheless "did not seek assistance with the design from Dr. Reay [the principal of ARCE] or anyone outside of ARCE" . ${ }^{6}$ Alan Reay himself did not check or review any structural details for the building either. Based on the structural drawings of David Harding, the Christchurch City Council (CCC) granted the building permit on 30 September $1986 .^{7}$

\footnotetext{
${ }^{5}$ Royal Commission Vol. 6, 302 .

${ }^{6}$ Ibid.

${ }^{7}$ Royal Commission Vol. 6, 73.
} 
As far as the phase of designing the building was concerned, the Royal Commission came to the following conclusion:

We have found that there were a number of noncompliant aspects of the CTV building design. We have concluded that a primary reason for this was that Mr Harding was working beyond his competence in designing this building. He should have recognized this himself, given that the requirements of the design took him well beyond his previous experience. We also consider that Dr Reay was aware of Mr Harding's lack of relevant experience and therefore should have realised that this design was pushing him beyond the limits of his competence. Dr Reay should not have left Mr Harding to work unsupervised on the design or without a system in place for reviewing the design, either by himself or someone else qualified to do so. The process led to a building design that was deficient in a number of important respects. ${ }^{8}$

\subsubsection{Articulated Concerns and Misplaced Pragmatism}

At the Christchurch City Council, two engineers were concerned with the construction project and the processing the application for a building permit submitted by ARCE on 17 July 1986. One was Bryan Bluck, the responsible buildings engineer, the other one Graeme Tapper, his deputy. ${ }^{9}$ Tapper who was in charge of reviewing the application for the building permit raised several concerns, both formal and substantive in nature, including missing calculations of the structural design. Although the Royal Commission could not entirely reanalyze whether or not ARCE responded to these demands, David Harding of ARCE did send further structural drawings and additional calculations to the CCC on 5 September 1986 and it was on 30 September 1986, after verification by Graeme Tapper, that the building permit was issued. ${ }^{10}$

As the Royal Commission found out, Mr. Tapper, through signing off on the structural design of the building on 10 September 1986, had approved the application for the building permit although his previous worries were not cleared. A crucial flaw of the structural design of the building indicated by himself in a letter to ARCE of 27 August 1986 had not been addressed in the additional drawings and calculations submitted by David Harding. Objections concerned the diaphragms at the ends of

\footnotetext{
${ }^{8}$ Royal Commission Vol. 6, 302.

${ }^{9}$ Royal Commission Vol. 6, 303.

${ }^{10}$ Royal Commission Vol. 6, 303.
} 
the beams connecting of the floors to the north wall complex of the building which Tapper diagnosed as inadequate and non-compliant with the relevant regulation. The regulation was the CCC Building Bylaw 105 that adopted New Zealand Standards for the design of buildings to the local conditions. ${ }^{11}$

The fact of the matter was, however, that Graeme Tapper had been instructed to issue the permit for the building against his own professional judgment. That instruction came from Tapper's immediate superior, Bryan Bluck, the CCC's Chief Buildings Engineer. It also turned out that Bluck had been approached by Alan Reay, principal of ARCE, in person who, according to the findings of the Royal Commission, "convinced $\mathrm{Mr}$ Bluck that Mr Tapper's concerns were unfounded" whereupon "Mr Bluck instructed $\mathrm{Mr}$ Tapper to sign off on the design, despite his concerns". ${ }^{12}$ The Royal Commission left no doubt that issuing the permit and the irregular behavior of Bryan Bluck made it possible to approve a design that was not in compliance with the relevant bylaw as it was valid and applicable at the time the permit was issued. ${ }^{13}$

It was most probably at the flawed diaphragms diagnosed correctly by Graeme Tapper that the structure of the CTV building started to disintegrate after the earthquake of 22 February 2011. ${ }^{14}$ The Royal Commission found out that, unlike what was usual practice, the surface of the precast beam ends had remained unroughened so that the joints of the coupling beams were not tight enough. ${ }^{15}$ One reason was that the roughening had not been envisaged in sufficient detail in the drawings of the design for which Harding was responsible. A second reason was that the roughening had not been performed on site as usual when the construction was under way. ${ }^{16}$ It would have been the task of the construction manager to check on this which, however, did not happen. ${ }^{17}$ At the time when the report of the Royal Commission was in the making, rumor spread that this manager had obtained a Bachelor of Engineering degree by fraud ${ }^{18}$ which he

${ }^{11}$ Royal Commission Vol. 6, 73. The relevant standards were NZS 3101 of 1982 and NZS 4203 of 1984.

${ }^{12}$ Royal Commission Vol. 6, 73.

${ }^{13}$ Royal Commission Vol. 6, 73-74.

${ }^{14}$ HCL \& SSL Report, 34-38.

${ }^{15}$ Royal Commission Vol. 6, 90; HCL \& SSL Report, 182.

${ }^{16}$ Royal Commission Vol. 6, 90.

${ }^{17}$ Royal Commission Vol. 6, 91.

${ }^{18}$ Royal Commission Vol. 6, 96. 
eventually admitted in the course of investigations by the Australian Federal Police. ${ }^{19}$

According to the findings of the Royal Commission, it was usual practice at the CCC, back in the 1980s, that applications for building permits were submitted and filed with architectural drawings only with structural drawings plus related calculations still to come. According to testimonial evidence before the Royal Commission this was typically the case when time was of the essence and contractors/consultants were eager to save time and to get the project moving through the CCC as quickly as possible. ${ }^{20}$ This also was against the bylaw 105 according to which every application for a building to be permitted required the submission of complete information about "the exact nature and character of the proposed undertaking and the provision made for full compliance with the requirements of this bylaw" 21 to which necessarily belonged the essentials of the structural design of the building. The fact that filing and processing permit applications without complete sets of structural drawings was common practice at the CCC explains why Graeme Tapper as the CCC engineer in charge did not insist on the submission of the calculations he had asked for in the first place.

The Royal Commission stated in its report that, according to testimonial evidence, the mid-1980s was "a demanding period with a large volume of applications for building permits and a great deal of pressure". ${ }^{22}$ The general directive was "to get permits through and buildings up". ${ }^{23}$ One coping pattern developed under these conditions was that Bryan Bluck as CCC's Chief Buildings Engineer sat down with the designer of a building and discussed issues of structural engineering in detail in meetings "sometimes lasting a whole day and usually ending with the designer completing a specifically worded design certificate". ${ }^{24}$ This was, on the one hand, a remarkable sign of flexibility and commitment on behalf of the CCC but, on the other hand, a temptation to make the enforcement of regulatory requirements negotiable at the expense of professional standards and, ultimately, CCC's institutional integrity. Certainly, this practice was meant to be a sign of pragmatism and good will as far as the CCC was

\footnotetext{
19 "Fake engineer found guilty," Engineers Australia, 18 August 2014.

${ }^{20}$ Royal Commission Vol. 6, 75 .

${ }^{21}$ Ibid.

${ }^{22}$ Ibid.

${ }^{23} \mathrm{~A}$ CCC official as quoted by the Royal Commission Vol. 6, 75.

${ }^{24}$ Ibid.
} 
concerned and for the sake of efficient service delivery. It was obviously under these conditions and in accordance with a pragmatic attitude "to get things done" that CCC's Chief Buildings Engineer Bryan Bluck instructed his second in command, Graeme Tapper, to issue the permit for the future CTV building after an extended conversation Bluck had held with Alan Reay of ARCE despite Tapper's concerns about the floor diaphragms.

The Royal Commission, in its report, aptly characterized the chosen approach of the CCC and of Bryan Bluck as Chief Buildings Engineer as "pragmatic" but risk prone. ${ }^{25}$ On the one hand, Bluck had authored internal guidelines for the structural checking process that encouraged CCC's engineers to rely on the "recognized expertise" of a Professional Designer for the certification of the structural design of a building rather than to conduct the relevant checking in the form of complex and time-consuming calculations themselves. On the other hand, the same document made CCC engineers explicitly responsible for the verification of compliance with the building bylaw provisions and stated: "Do not amend the BPA [building permit applicant's] drawings in any way (in order to expedite the permit process), as to do so could compromise the responsibility for the specific design which otherwise fully belongs to the Professional Designer." ${ }^{26}$ So, in the essence, these instructions were highly ambiguous. They reminded CCC engineers of their undeniable responsibility for the verification of an applicant's strict compliance with the relevant legal provisions while at the same time encouraging them to delegate de facto that responsibility to a Professional Designer-in other words, a private firmwithout specifying on whose behalf the designer would conduct his or her checking procedures. Regardless of their strict and explicit wording, Bluck's guidelines rather distorted than clarified accountability. The consequences for the actual compliance with the provisions of the building bylaw were rather mildly circumscribed in the report of the Royal Commission in stating that this "approach [was] accompanied by some risks, including the risk that a non-complying would be approved" by the CCC. ${ }^{27}$ The flipside of what the Commission appropriately denoted as a "pragmatic" arrangement was the convergence of counterproductive incentives on both ends, the CCC and a private Professional Designer, to expedite the structural checking process while implicitly maintaining the

\footnotetext{
${ }^{25}$ Royal Commission Vol. 6, 76.

${ }^{26}$ Ibid.

${ }^{27}$ Ibid
} 
option of blame shifting if need be. For instance, in case of 'collateral damages' of an accelerated checking process in the form of non-compliance with the existing legal provisions and resulting safety risks.

In the case of the CTV building these counterincentives were toxic. On both ends, the CCC and ARCE as the "Professional Designer", professional competence and integrity was weakened. The critical assessment of the flawed diaphragms articulated by Graeme Tapper as CCC's buildings engineer in charge was overruled by his superior Bryan Bluck. Bluck, according to his own guidelines, invested full trust in Dr. Alan Reay, the principal of ARCE, with whom he had an extended meeting prior to his decision passed down to Mr. Tapper to issue the construction permit. The true tragedy was that that trust was entirely unjustified. And although Alan Reay was necessarily unaware of the substantial deficiencies of ARCE's expertise, Bryan Bluck was responsible for guidelines that implicitly encouraged CCC's engineers to take the expertise of any Professional Designer for granted.

Yet the problem was not primarily the guidelines themselves but the fact that no provision had been made for their careful and case-by-case application. A mindful use of the guidelines should have made sure to conduct scrutiny of structural design issues to be performed solely by CCC engineers. The fact that Graeme Tapper as the CCC buildings engineer in charge had raised such doubts should have been reason enough to initiate a detailed review of the submitted application. Instead, Bryan Bluck as chief buildings engineer gave carte blanche to a private consultancy firm as Professional Designer despite the reluctance of CCC's buildings engineer immediately responsible to issue the building permit. ${ }^{28}$

\subsubsection{Delegation to Incompetent Personnel}

What was with necessity beyond the control of the CCC and thus of Buildings Engineer Tapper was the insufficient professional competence and experience of the immediately responsible ARCE engineer, David Harding. According to all evidence in hindsight, it was no coincidence that ARCE did not respond to Graeme Tapper's request to furnish the city council with full documentation, especially calculations, about the critical

\footnotetext{
${ }^{28}$ Graeme Tapper's request of 27 August 1986 for additional calculations and documentation addressed to ARCE to which ARCE never responded in detail is reproduced in the report of the Royal Commission Vol. 6, 77-78.
} 
structural engineering components of the planned building. Harding was presumably just not capable to run those calculations. With ARCE not coming up with the requested documentation all alarm bells should have been ringing at the CCC. Instead, the building permit was issued without further ado.

The Royal Commission stated clearly that "Mr Harding was acting outside of his competence in designing the CTV building". ${ }^{29}$ Harding had no experience with multi-story building designs and no experience with the computer program which was the then current version of ETABS (Integrated Analysis, Design and Drafting of Building Systems). It turned out that Harding, instead of making his own calculations, whether by hand or computer-assisted, was just using the calculations made by his predecessor, John Henry, for a different building of the same type, known as Landsborough House. ${ }^{30}$ Harding nonetheless remained unaware that Henry had revised the Landsborough House design and, as a consequence, had added additional reinforcements.

The Royal Commission did not only underline the lack of competence of Harding but especially his unwillingness to acknowledge these deficiencies and to ask for assistance. ${ }^{31}$ The commission also emphasized, however, that it would have been Alan Reay's obligation to verify if and to what extent David Harding was up to the job assigned to him. ${ }^{32}$ In the hearings of the commission Reay, in turn, admitted that, back in 1986, he had trusted Mr. Harding's self-assessment and that he took it for granted that otherwise David Harding would have approached him and asked for help. It was also evident that, on the one hand, Alan Reay had hired David Harding for a senior position because he trusted his ability while, on the other hand, Harding, assuming that position, presumably saw no easy way to admit that he was not entirely fit for the job. ${ }^{33}$ One indicative argument of Alan Reay before the Royal Commission was that instead of closely supervising the work of Harding he "relied on the CCC to review the design during the permit process". ${ }^{34}$ Which only underlines the vicious circle of blame shifting in the relationship between ARCE and the CCC.

\footnotetext{
${ }^{29}$ Royal Commission Vol. 6, 65.

${ }^{30}$ Royal Commission Vol. 6, 67.

${ }^{31}$ Ibid.

${ }^{32}$ Royal Commission Vol. 6, 68.

${ }^{33}$ The Royal Commission alluded to this problem only implicitly. Cf. Vol. 6, 67, 71.

${ }^{34}$ Royal Commission Vol. 6, 70 .
} 


\subsubsection{Compromised Professional Integrity}

The application for the permit for the CTV building was formally filed by Alun Wilkie Associates, the actual contactor, on 17 July 1986. ${ }^{35}$ It carried the handwritten note: "Structural Drawings to come". The structural drawings themselves were received by CCC on 22 August 1986. A further set of structural drawings was submitted on 5 September 1986. As mentioned above, Graeme Tapper as the engineer in charge at the CCC signed off on the structural aspects of the design on 10 September 1986 despite his concerns about "a significant structural issue in the design, namely the connection of the floors (diaphragms) to the north wall complex" ${ }^{36}$ which had not been amended by ARCE in the submitted design. The permit itself was issued on 30 September 1986 upon direct instruction by CCC's chief buildings engineer Bryan Bluck.

According to the assessment of the Royal Commission, the calculations in support of the structural design of the building requested by Tapper on 27 August 1986 were never submitted by ARCE. ${ }^{37}$ Testimonial evidence before the Royal Commission underlined that the personal relationship between David Tapper and his superior Bryan Bluck was difficult. ${ }^{38}$ Tapper was described by staff members who had worked with him at the CCC as a "very thorough person" with "a good sense of the potential weak points" in a submitted structural design of a building and "little tolerance for consulting engineers who submitted poor details or incomplete work". ${ }^{39}$ Accordingly, the Royal Commission focused specifically on the very question why Tapper had signed off the plans submitted by ARCE in the form they were ultimately permitted by the CCC despite the deficiencies identified by himself.

It turned out in the hearings before the Royal Commission that it was, according to one testimony, "not uncommon for Alan Reay [the principal of ARCE] to go directly to Bryan Bluck [CCC's chief buildings engineer] to obtain the release of a building consent when he could not get approval from Graeme Tapper", a characterization that Alan Reay himself denied

\footnotetext{
${ }^{35} \mathrm{~A}$ facsimile of the form sheet used for the application is reproduced in the report of the Royal Commission, Vol. 6, 72 .

${ }^{36}$ Royal Commission Vol. 6, 73.

${ }^{37}$ Royal Commission Vol. 6, 80 .

${ }^{38}$ Royal Commission Vol. 6, 82 .

${ }^{39}$ Ibid.
} 
before the commission. ${ }^{40}$ As a matter of fact, the Royal Commission had no doubt that arguments between Tapper and Bluck had occurred quite frequently and "sometimes resulted in Mr Bluck overruling Mr Tapper". ${ }^{41}$ It was confirmed through testimonial evidence that it was even heard through the "engineers' grapevine" that "a new building in Christchurch had been the subject of some contention in relation to the issue of a building permit" 42 and that Graeme Tapper and Bryan Bluck were the key opponents. The Royal Commission had no doubt that "there was a difference of opinion between Mr Tapper and Mr Bluck about the structural integrity of the design" of the building. ${ }^{43}$

The Commission also accepted the evidence by Graeme Tapper's widow that her husband had "told her he did not want to sign the building off but was under pressure from Mr Bluck to do so". ${ }^{44}$ The Commission concluded:

Mr Bluck then instructed Mr Tapper to sign off on the CTV building, which he did on 10 September 1986. This evidence, if we were to accept it, would explain how the building came to be permitted despite the floor connection being non-compliant [with the relevant Building Bylaw] and Mr Tapper having recognised this. ${ }^{45}$

The report of the Royal Commission also revealed the bizarre detail that Alan Reay did confirm that he had a meeting with Bryan Bluck that resulted in Bluck overruling the concerns of Graeme Tapper but that "Dr Reay himself ... knew very little about the structural detail of the building”. This illustrates how thin the ice was on which both Reay and Bluck based their conviction that Graeme Tapper's concerns about the structural integrity of the building's design were unfounded and how ethically questionable their determination was to overrule those concerns. The Royal Commission concluded:

${ }^{40}$ Ibid.

${ }^{41}$ Ibid.

${ }^{42}$ Royal Commission Vol. 6, 83 .

${ }^{43}$ Royal Commission Vol. 6, 84 .

${ }^{44}$ Ibid.

${ }^{45}$ Ibid. - The Royal Commission discussed thoroughly the validity of evidence from hearsay in this context but concluded that the relevant statements referring to the character of both Bluck and Tapper and of the situation in question were reliable. 
It is therefore difficult to understand how he [Alan Reay] was in a position to give any proper assurance in relation to the design. ${ }^{46}$

The Royal Commission found sufficient evidence in support of the assessment that Dr. Reay's "assurances" did decisively influence Bryan Bluck's opinion about the design issue raised by Graeme Tapper. Bluck's former deputy, Peter Nichols, testified before the Commission that Bluck, whom he had met by mere chance right in front of the construction site, had confirmed that what was to be heard "through the grapevine" in the Christchurch engineering community about a quarrel between him, Bluck himself and Tapper, was true but that Alan Reay had convinced him that Tapper's reservations were unfounded. The Royal Commission concluded "that Dr Reay's involvement in the permitting process contributed, at least to some extent, to the wrongful permitting of the building" ${ }^{47}$ The blunt truth was that Bluck, through conceding this kind of personal influence to an applicant seeking a building permit in the explicit attempt to overcome the reservations articulated within the CCC, compromised his own professional integrity as well as the integrity of the institution he was running.

\subsubsection{Institutionalized Error}

There were opportunities to neutralize the path dependent errors evolving from the CCC's inability to perform proper licensing of the CTV building. In early 1990, the Canterbury Regional Council (CRC) considered to purchase the building and engaged a consulting firm, Holmes Consulting Group (HCG), to prepare a structural report that, when finished, was submitted to the CRC on 31 January 1990. The HCG report noted "a vital area of non-compliance [with the relevant design codes]" 48 in the connection of the floors to the north wall complex-in other words exactly what CCC's buildings engineer Graeme Tapper had detected when reviewing the application for the building permit before being overruled by his superior Bryan Bluck. In protracted discussions between HCG engineers and representatives of the actual designers of the CTV

\footnotetext{
${ }^{46}$ Royal Commission Vol. 6, 88 .

${ }^{47}$ Ibid.

${ }^{48}$ Royal Commission Vol. 6, 101.
} 
building-ARCE, meanwhile renamed ARCL-a plan for "remedial work" was drafted. It was shelved though until October 1991. ${ }^{49}$

The HCG engineer in charge in January 1990 was John Hare. Hare had architectural drawings at his disposal on the basis of which he carried out an "approximate seismic analysis". ${ }^{50}$ It was on this basis alone that $\mathrm{Mr}$. Hare determined the existence of "an area of non-compliance with the code of the day with respect to the tying of the floors to the shear walls, specifically to the north core walls". ${ }^{51}$ In a draft report Hare referred to this observation as a "vital area of non-compliance with current design codes". 52

John Hare had several meetings with Alan Reay and with Geoffrey Banks who was a major shareholder of ARCL. The original design engineer, David Harding, was not available anymore since he had left the firm. Which necessarily impacted on the consistency of relevant information concerning the structural design of the CTV building. It turned out that Hare had a much more precise diagnosis of the structural flaws of the building's design than Reay and the responsible buildings engineer of the CCC, Bryan Bluck, in their own deliberations of September 1986. According to Hare's judgment, Harding's design calculations did not address the critical tie force originating from an earthquake in the north south direction but only potential forces in the east west direction. Hare also pointed to the fact that the actual floor diaphragms connecting the building itself to the north wall complex was "punctured by the lift, stair and service risers" ${ }^{33}$ so that the "relatively few direct connections from the floor diaphragm to the north wall complex and there appeared to be insufficient reinforcement tying the floors and north wall complex together". ${ }^{54}$

It is indicative that a seasoned engineer like John Hare, on the basis of design drawings and personal inspection of the building, was able to make a concise and, basically, alarming judgment about the structural condition of the building's architecture. So the episode one more illustrates what could have been achieved if only the responsible engineers in charge on both ends, ARCE/ARCL and the Christchurch City Council, would have been as diligent as Hare was as a single engineer occupied with the matter

\footnotetext{
${ }^{49}$ Royal Commission Vol. 6, 100-109.

${ }^{50}$ Royal Commission Vol. 6, 100.

${ }^{51}$ Ibid.

${ }^{52}$ Quoted in Royal Commission Vol. 6, 100.

${ }^{53}$ Quoted in Royal Commission Vol. 6, 100.

${ }^{54}$ Ibid.
} 
just for a short period of time. In cross-examination before the Royal Commission both Reay and Banks accepted the assessment that the issue identified back in 1990 by John Hare "was a critical structural weakness" and in terms of "fundamental engineering", according to Alan Reay himself, a "straight blunder". 55

Even more indicative and disturbing is, however, that the chief buildings engineer of the CCC, Bryan Bluck, in a meeting with John Hare of 29 January 1990, missed the opportunity to focus Hare's attention to the concerns previously articulated by Bluck's subordinate engineer Graeme Tapper. "Mr Hare's purpose," the Royal Commission reported, "was to ascertain whether the CCC had identified any issues during the building permit and construction process". ${ }^{56}$ The correct answer would have been a straight Yes. Instead, according to Hare's statement before the commission, "Mr Bluck raised three issues unrelated to the structure of the building" while Hare did not see any of the relevant CCC files. ${ }^{57}$

On 31 January 1990, HCG submitted a preliminary report to the Canterbury Regional Council whose crucial parts could not have been more explicit:

A vital area of non-compliance with current design codes, seen in the documents, is in the tying of the floors to some of the shear walls. This item is under review with the original consultants [ARCE/ARCL], but if confirmed will require potentially expensive remedial work. However, this cost is a matter for discussion between the current owner and their consultants. (...) An area of concern however has been discovered in the connections of the structural floor diaphragm to the shear walls. While this is not a concern on the coupled shear wall to the south of the building, connections to the walls at the North face of the building are tenuous, due to penetrations for services, lift shafts and the stairs, as detailed on the drawings. The result of this would be that in the event of an earthquake, the building would effectively separate from the shear walls well before the shear walls themselves reach their full design strength. Discussion has continued on this matter with Mr Geoff Banks of Alan Reay Consulting Engineer, and it currently appears that there may have been some provision made for this during construction. However, no documentation apparently exists, so it would only be safe to assume that this aspect fails to comply with current design codes. ${ }^{58}$

\footnotetext{
${ }^{55}$ Reay's statement quoted in the report of the Royal Commission, Vol. 6, 100.

${ }^{56}$ Ibid.

${ }^{57}$ Ibid.

${ }^{58}$ Quoted in Royal Commission Vol. 6, 101.
} 
Hare's statement together with an assessment of the approximate costs of "remedial structural works" for fixing the defects identified in the floor connections resulted in the decision of the Canterbury Regional Council not to purchase the CTV building.

Triggered by Hare's report, ARCL as the original designer of the CTV building took issue with the identified defects of the structural design of the building was, from early February 1990 on, in constant contact with two HCG engineers, Grant Wilkinson and John Hare himself. The subject of these verbal and correspondence based exchanges was the nature of the structural defects identified by Hare and the potential costs of "remedial works". ${ }^{59}$ There were, according to the evidence mobilized by the Royal Commission, divergent assessments of Banks of ARCL on the one hand and Hare of HCG on the other hand and in an "annual report" to the umbrella organization Consulting Engineers Advancement Society (CEAS) of 9 April 1990, Banks wrote that ARCL was "still investigating whether there is a deficiency [concerning the structure of the CTV building], and if so, details of remedial work". ${ }^{60}$

No further investigations took place though. According to the findings of the Royal Commission, in "a period of approximately one year until February 1991 ... it appears that nothing was done by Dr Reay or $\mathrm{Mr}$ Banks to address the issue". ${ }^{61}$ This, however, was plausibly explained by Alan Reay in cross-examination before the Royal Commission by stating that neither ARCL had been informed that HCG was no longer involved in any further examination (because the engagement of HCG had been terminated by the Canterbury Regional Council in early February 1990) nor was there, in the perception of Reay himself or Geoffrey Banks, any reason to assume that a purchaser of the CTV building would refrain from further investigations.

When an article in the Christchurch newspaper The Press on 4 February 1991 reported that the CTV building had been sold indeed, Reay and Banks did take the initiative to inform the new owner, Madras Equities, about "the issue with the floor connections". ${ }^{2}$ Due to consultation with their insurer regarding the consequences of potential liability in case design errors should be detected in course of another investigation, the

\footnotetext{
${ }^{59}$ Royal Commission Vol. 6, 103.

${ }^{60}$ Quoted in Royal Commission Vol. 6, 105.

${ }^{61}$ Ibid.

${ }^{62}$ Ibid.
} 
insurer confirmed in 1991 the agreement that the new owner should be informed by ARCL. However, in a period of five more months nothing was done to notify the new owner of the CTV building. The report of the Royal Commission noted, "it is difficult to reconcile this delay with Dr Reay's acceptance that once there was a new owner there was some urgency to notify". ${ }^{63}$

Finally, on 11 September 1991, Geoffrey Banks wrote a letter to inform the new owner on behalf of ARCL. The owner was Madras Equities Ltd. represented by Mr. Russel Ibbotson. The existence of that letter the original of which remained undetectable for the Royal Commission became apparent through the response letter of Ibbotson of 30 September 1991. Ibbotson referred to the description of the "remedial work" by Geoffrey Banks which, according to Banks, "if required, will be relatively simple to carry out whilst the building is predominantly unoccupied and should not involve a major expense outlay". Ibbotson's description of the content of Banks' letter went on in direct quotation: "It is also noted that [according to Banks] it is a possibility that the apparent problem may not, in fact, be a problem and that this can only be determined by further work involving some drilling to determine the extent to the reinforcing steel work in position." $" 64$

It was a bitter irony that Banks' counsel before the Royal Commission stated "that Mr Banks had been told by Dr Reay that the issue might have been addressed during construction and Mr Banks reasonably thought that may have been the case as the building had been given a building permit." ${ }^{65}$ Which not only underlines the negative impact of insufficient documentation of the original design procedure and related calculations but also a fateful vicious circle: Initially, in September 1986, the chief buildings engineer of the Christchurch City Council, Bryan Bluck, had overruled the objections of his subordinate fellow engineer Tapper in accordance with what Alan Reay as principal of the consultancy firm ARCL (then ARCE) had told him about the soundness of the structural design of the CTV building. Now, in September 1991, Geoffrey Banks accepted without further verification virtually the very same narrative of his superior Alan Reay on which he based his own statement vis-à-vis the new owner of the CTV building. He did that, however, in reference to the fact that,

${ }^{63}$ Ibid.

${ }^{64}$ Quoted in Royal Commission Vol. 6, 106.

${ }^{65}$ Ibid. 
after all, the CCC had issued a permit for the building. So, the error became institutionalized.

To which contributed a conflict of interests. Although ARCL had obtained the agreement of its insurer to inform the new owner about the issues with the structural design of the CTV building the dimension of potential liability was incalculable. In the end, what remained of John Hare's (HCG) statement about "a vital area of non-compliance with current design codes, seen in the documents, is in the tying of the floors to some of the shear walls" of 31 January 1990 was Banks' (ARCL) reference to "a possibility that the apparent problem may not, in fact, be a problem". ${ }^{66}$ The Royal Commission could not help stating, "We consider that while there appears to have been an element of minimisation in the actions of Dr Reay and Mr Banks, this was likely motivated by the perceived need to protect the insurance cover and does not, in our view, imply any ulterior motive." 67

Now that the existence of "problems" with structural defects of the CTV building was finally brought to the attention of the new owner, Madras Equity, the responsibility for the appropriate calculations and design lay again with Reay and Banks of ARCL. The "remedial works" ultimately carried out consisted of drag bars as fortifying connection between the floors and the north wall complex at the upper levels of the CTV building (levels 4, 5 and 6). ${ }^{68}$ These works were performed in October 1991. That happened without a building permit from the CCC. It would have been the obligation of ARCL though, i.e., of Alan Reay and Geoffrey Banks, to apply for such permit. This, however, was omitted as well. The Royal Commission stated that although the relevant legal stipulations "may have been widely framed, we think it clear that this structural work required a permit". ${ }^{69}$

Again, Alan Reay made a revealing statement before the commission in saying that, "based on his experience in dealing with Mr Bluck [the CCC's chief buildings engineer] over many years he believed Mr Bluck's view would have been that the retrofit works [= installation of the drag bars] were part of the original job and that no permit was required, although

${ }^{66}$ Indirect quote from Mr. Ibbotson's response letter of 30 September 1991 in Royal Commission Vol. 6, 106.

${ }^{67}$ Ibid.

${ }^{68}$ Royal Commission Vol. 6, 107.

${ }^{69}$ Royal Commission Vol. 6, 108. 
Mr Bluck might have asked to receive details about what was undertaken". ${ }^{70}$ Which implies that Reay was not able or not willing to distinguish between the institutional role and duty of the CCC and his personal relationship with Bryan Bluck at the CCC's chief buildings engineer. The Royal Commission stated "that the failure to apply for a permit was a clear omission, which meant that the inadequacy of the floor connections to the north wall complex in the original design was not drawn to the CCC's attention in 1991". ${ }^{71}$

The bottom line was indeed that, contrary to relevant legal prescriptions, the relevant public authority as the professional and neutral guardian of the public interest in the safety of buildings remained uninvolved. The Royal Commission highlighted with latent sarcasm that "so many people were aware of the issue with the connection of the floors to the north wall complex over some years, without the CCC ever being made aware of it". ${ }^{72}$ This observation does not alter the fact though that the CCC had issued a building permit back in September 1986, which, according to the Royal Commission's own judgment, should never have been granted. The Commission came to the conclusion that it was indeed at the joints between floors and both the north wall complex and the south shear wall that the structure of the CTV building started to disintegrate on 22 February 2011 :

All of the floors dropped, virtually straight down, due to major weaknesses in the beam-column joints and the columns. (...) The north wall complex was left standing, the floors having torn away and come to rest stacked up adjacent to its base. The south shear wall collapsed inwards on top of the floors in what we consider would have been the last part of the collapse sequence. The observed damage of both of these walls show that they had not been able to perform their intended role. ${ }^{73}$

\subsubsection{The Legacy of Errors: The Aftermaths of the 4 September 2010 Earthquake}

The structural design errors committed by David Harding of ARCE/ ARCL and not detected by the CCC which issued the building permit on

\footnotetext{
${ }^{70}$ Royal Commission Vol. 6, 109.

${ }^{71}$ Ibid.

${ }^{72}$ Ibid.

${ }^{73}$ Royal Commission Vol. 6, 262.
} 
30 September 1986 nor in the course of the reinforcement of the floor diaphragms in 1991 constituted a necessary but not a sufficient condition for the failure of the CTV building on 22 February 2011. It took a series of earthquakes and aftershocks plus a series of additional errors and omissions of the Christchurch City Council to make the collapse of the CTV building the catastrophic event that claimed the lives of 115 people.

On 4 September 2010 at 4:35AM an earthquake of 7.1 magnitude shattered Christchurch whose epicenter was about 40 kilometers west of the city "on a previously unknown fault beneath the Canterbury Plains". ${ }^{74}$ On boxing day 2010 (26 December), several aftershocks followed with a minor magnitude of 4.6 to 4.7 whose epicenter was just 3.7 to 7 kilometers away from the Christchurch central business district (CBD) where the CTV building was located on 249 Madras Street.

After the earthquake of 4 September 2010 the CTV building still stood tall and without visible damages for laypeople's eyes except for broken windows. Like dozens of other buildings in the CBD alone, the CTV building was subject to several inspections whose preliminary outcome was the classification of buildings according to damages and related safety statuses. The status assignment followed a traffic light pattern with "green" for buildings sound and safe, "yellow" for buildings with detected or presumed structural damages and "red" for seriously damaged buildings at risk of collapse. CCC inspectors used placards in the respective colors to mark the buildings visibly at the outside, usually at the main entrance. A green placard indicated that "no restriction on use or occupancy" was imposed (Illustration 4.3). ${ }^{75}$

The inspection and the marking of the buildings took place under the condition of a state of local emergency that had been declared in Christchurch immediately after the earthquake of 4 September 2010 and in the framework of a Civil Defense Emergency Management Response initiated by the CCC. ${ }^{76}$ It was conducted at two levels of urgency called Level 1 Rapid Assessment and Level 2 Rapid Assessment. The Level 1 Rapid Assessment (L1RA) of the CTV building was conducted on the afternoon of 5 September by a CCC inspector, Peter Van der Zee, and Richard Sullivan, a chartered Professional Engineer, plus two Urban

\footnotetext{
${ }^{74}$ Royal Commission Vol. 6, 120.

${ }^{75}$ Royal Commission Vol. 6, 124.

${ }^{76}$ Ibid.
} 


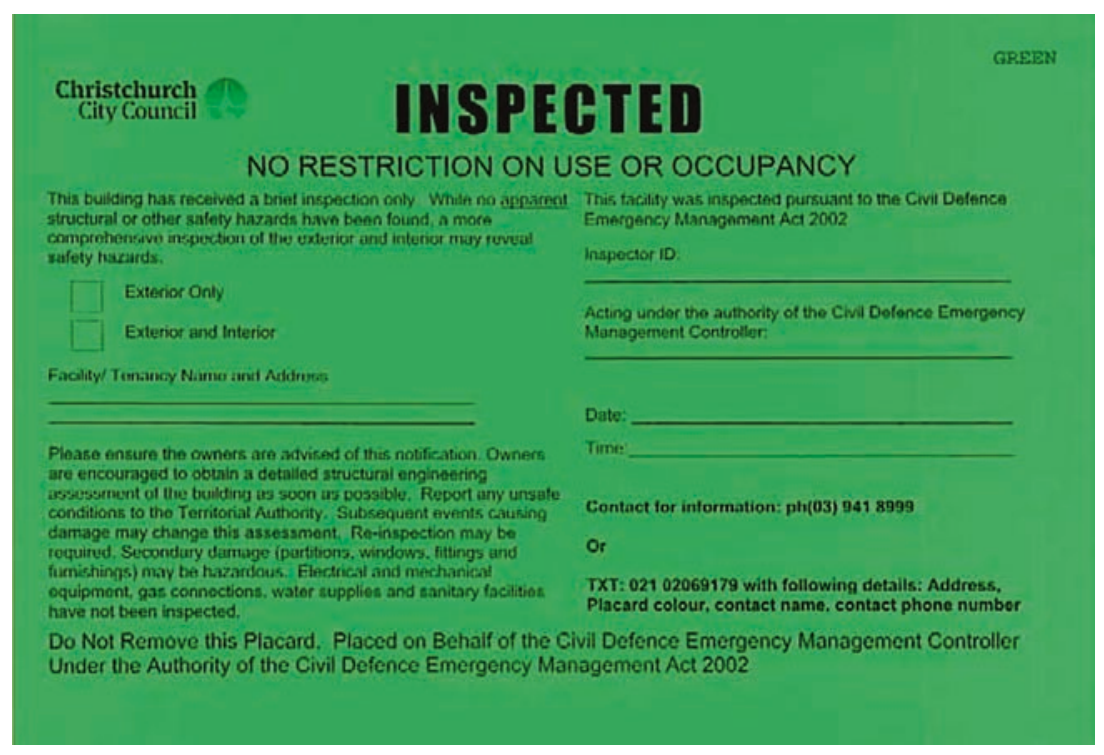

Illustration 4.3 Green Placard used to mark buildings after the 4 September 2010 earthquake in Christchurch. (Source: Royal Commission Vol. 6, p. 131)

Search and Rescue (USAR) officers who remained unidentifiable for the Royal Commission. ${ }^{77}$

Van der Zee, according to the findings of the Royal Commission, had three years' experience on his job but no experience in building inspection. During cross-examination before the Commission, Van der Zee "said he had no training in post-earthquake building assessments before the September earthquake, nor had the majority of CCC building officers who carried out assessments at that time" ${ }^{78}$ According to this first assessment conducted by Van der Zee on behalf of the CCC "the estimated overall building damage was "None" ${ }^{79}$ The inspection team thus allocated a green placard to the CTV building. The green placard a facsimile of which, in original color, is reproduced in the report of the Royal Commission $^{80}$ carried the wording: "This building has received a brief

\footnotetext{
${ }^{77}$ Ibid.

${ }^{78}$ Royal Commission Vol. 6, 126.

${ }^{79}$ Royal Commission Vol. 6, 124.

${ }^{80}$ Royal Commission Vol. 6, 131.
} 
inspection only. While no apparent structural or other safety hazards have been found, a more comprehensive inspection of the exterior and interior may reveal safety hazards." 81 The header read in capital letters and partly in bold, "Inspected. No restriction on use or occupancy". At the same time, the wording of the green placard entailed the following:

Please ensure the owners are advised of this notification. Owners are encouraged to obtain a detailed structural engineering assessment of the building as soon as possible. ${ }^{82}$

Quite obviously, this very first inspection was a routine operation and the CCC or USAR inspectors had based the grading of the building solely on a visual assessment with no reason or motivation whatsoever to suspect the structural damages, let alone inherent instability, of the building.

The compulsory Level 2 Rapid Assessment (L2RA) took place on 7 September 2010 initiated by a Building Evaluation Manager in the Christchurch City Emergency Operation Center, Stephen McCarthy. ${ }^{83}$ McCarthy asked the CCC three buildings to be "urgently" inspected, including the CTV building. The task was assigned to three inspectors who happened to be extraordinarily experienced CCC staff members: David Flewellen, Russel Simson and Graham Calvert. However, none of them was an engineer. When cross-examined by the Royal Commission, McCarthy mentioned the tense situation after the earthquake with countless inspections to be performed so that "all available engineers had been dispatched elsewhere" ${ }^{84}$ McCarthy also maintained, however, he would have told the three CCC inspectors "that if there were any issues then they should request that an engineer inspect the building". ${ }^{85}$ In his own recollection, Flewellen, Simson and Calvert were also encouraged to advise "the owner [of the building] to engage an engineer". ${ }^{86}$ Which was just in accordance with the wording on the green placard assigned to the building two days earlier. ${ }^{87}$ Nonetheless, the three inspectors received mixed messages from McCarthy. On the one hand, they were encouraged to

\footnotetext{
${ }^{81}$ Ibid.; the word "apparent" was underlined on the original placard.

${ }^{82}$ Ibid.

${ }^{83}$ Royal Commission Vol. 6, 126.

${ }^{84}$ Quoted by the Royal Commission. Cf. Vol. 6, 126.

${ }^{85}$ Ibid.

${ }^{86}$ Ibid.

${ }^{87}$ Ibid.
} 
request a CCC engineer if necessary, on the other hand they were told to tell the owner of the building to engage (and to pay) an engineer himself. That must have raised the threshold to approach McCarthy with the request for dispatching an engineer for the inspection of the CTV building since it was common knowledge that the CCC engineers were extremely busy in the aftermath of the earthquake.

As the Royal Commission found out, Flewellen, Simson and Calvert were not even aware that a Level 1 Rapid Assessment had already taken place before their arrival at the CTV building where they found the green placard stuck to the main entrance of the building. ${ }^{88}$ The three inspectors talked to someone who, they thought, was the building manager but the person remained unidentifiable for the Royal Commission. ${ }^{89}$ Flewellen, Simson and Calvert did inspect the building but, as Flewellen admitted before the Royal Commission, only superficially. After all, they had noticed the green placard at the building's main entrance so that, in principle, they just looked around in various sections of the building but discovered "no structural abnormalities". ${ }^{90}$ Finally, the three inspectors issued their own green placard on that day, 7 September 2010. The Royal Commission came to the conclusion that this second inspection was characterized by "a lack of understanding of the Rapid Assessment process" and that the three inspectors clearly acted without clear instructions from the CCC. ${ }^{91}$ According to the findings of the commission, the inspectors "were confident that the person they spoke to had understood the importance of obtaining an independent engineering inspection". ${ }^{92}$

The immediate effect of the green placard classification was, however, the declaration of "no restriction on use or occupancy". This was, not surprisingly, instantly communicated to the various groups of occupants via circular mails. A message of the responsible CTV manager, Murray Wood, read: "We have just had an internal inspection of the building from 3 engineers and they have found that this building is in good condition and is deemed habitable." 93

So, in the essence, what was certainly meant to be a solid and standardized framework for scrutinizing the structural status of buildings was

\footnotetext{
${ }^{88}$ Royal Commission Vol. 6, 127.

${ }^{89}$ Ibid.

${ }^{90}$ Ibid.

${ }^{91}$ Royal Commission Vol. 6, 128, 130.

${ }^{92}$ Royal Commission Vol. 6, 128.

${ }^{93}$ Quoted in Royal Commission Vol. 6, 131.
} 
inappropriately handled. Part of the reason was the ambiguity of the inspection requirements themselves as far the engagement of trained engineers was concerned. It was left to the discretion of the inspectors-who, contrary to what CTV manager Wood wrote in his circular mail, were no engineers indeed-whether or not to ask CCC to send an engineer on site and their uncertainty what to do was not reduced by the wording of the green placard. In the end, the three CCC officers, when talking to the presumed building manager, just reiterated what the placard said which was to recommend the engagement of an engineer on behalf of the owner of the building. ${ }^{94}$

On the other hand, the official in charge at the CCC, McCarthy, in the middle of extreme workload after the earthquake of 4 September 2010, inevitably relied on Flewellen, Simson and Calvert as far as an in-depth inspection of the building was concerned. Yet, even if such an inspection would have been performed by a trained engineer no specific instructions existed about the nature of a more thorough scrutiny, for instance, whether it should pertain to structural analyses. Certainly, Flewellen, Simson and Calvert had only "limited training" for the job they were supposed to do ${ }^{95}$ and Simson admitted before the Royal Commission, "we should have probably at least put a yellow sticker on the building". "96 However, both the arrangement of oversight and control of the CCC officials on site and the ambiguous wording of the green placard created a diffusion of responsibility in the first place.

So, the Royal Commission itself remained uncertain if the presence of an engineer in the CCC inspection team would have made a difference. ${ }^{97}$ Unless, one might add, an inspecting engineer would have been specifically instructed or determined to perform a structural analysis of the building on the basis of sound documentation of the structure's architecture. Not only was there no plausible reason to conduct such a laborious, time consuming and, last but not least, expensive investigation nor was there any reason to assume that the structural design of the building had not been diligently inspected and certified in the first place. It is therefore only with a caveat that one can define the omitted in-depth inspection of the CTV building by an engineer as a missed opportunity - which it was from

\footnotetext{
${ }^{94}$ Royal Commission Vol. 6, 128.

${ }^{95}$ Royal Commission Vol. 6, 133.

${ }^{96}$ Royal Commission Vol. 6, 131.

${ }^{97}$ Royal Commission Vol. 6, 132.
} 
an objective point of view. That omission would not have done any harm under regular circumstances, i.e. if only the structural design of the building would have been subject to proper scrutiny and approval back in 1986 . And there was obviously every reason to take precisely this for granted. The tragedy was that, back then, a similar kind of diffused responsibilities between CCC's buildings engineer Tapper, his superior Bluck, and the principal of Alan Reay Consulting Engineer (ARCE), Mr. Reay himself, had created a situation in which such proper procedures were just not performed. Which in turn must have been beyond the imagination of CCC officials and any other person involved in the inspection procedures after the earthquake of 4 September 2010.

So it was not surprising that, when an inspection of the CTV building was indeed performed by an engineer in October 2010, it did not include a structural analysis of the building's design either. ${ }^{98}$ The engineer, David Coatsworth, was a senior associate with CPG New Zealand Ltd. (CPG) with 40 years' experience in structural and civil engineering. He had been contacted on 7 September 2010 by the actual building manager, John Drew, immediately after what was supposed to be the Level 2 Rapid Assessment performed by Flewellen, Simson and Calvert earlier that day. Mr. Coatsworth inspected the building probably at the end of September 2010 (no exact date is mentioned in the report of the Royal Commission). The inspection remained visual-based but was nonetheless detailed and thorough. On a four hours tour throughout the entire building, accompanied by Mr. Drew and Mr. Lennart Pagan as an expert for necessary repairs, Mr. Coatsworth took 109 photographs, inspected every single column of the structure and spoke to occupants of the building who pointed him to assumed damages and described their observations since the earthquake of 4 September.

In an Email of 24 September 2010 sent by Coatsworth to Drew prior to the inspection Coatsworth had noted, "Structural and architectural drawings of the building would be very helpful. If these can be made available, they will help with the understanding of the structural systems within the building." ${ }^{99}$ Mr. Drew forwarded Coatsworth's request to the CCC only to be told that, due to the "disarray" connected to the earthquake of 4 September, it might take eight weeks or so before the relevant file was

\footnotetext{
${ }^{98}$ Royal Commission Vol. 6, 134.

${ }^{99}$ Royal Commission Vol. 6, 134.
} 
available. ${ }^{100}$ It turned out that the drawings were available earlier than expected when Coatsworth had not yet submitted his inspection report. When this came to the attention of Mr. Drew he did not notify Coatsworth though and Coatsworth himself did not insist on receiving the drawings. ${ }^{101}$ Quite ironically, this was criticized by Alan Reay's counsel before the Royal Commission as a "critical omission", a judgment which the Commission itself deemed "not justified". ${ }^{102}$ According to all likelihood, the statement of Alan Reay's counsel was designed to relativize the coresponsibility of his client for the original omission not to seek a permit for the installation of the drag bars in 1991 which would have been the opportunity to correct the design errors committed in the first place. On the other hand, the Royal Commission stated that if Mr. Coatsworth had had the structural drawings "this may have prompted him to reconsider the type of inspection he was carrying out to conduct a more invasive damage-based inspection". ${ }^{103}$ So the judgment of the Commission was itself ambiguous to some extent which was, however, probably due to the effort not to blame unfairly Coatsworth whose way of inspection was, according to the commission, "consistent with the approach of most, if not all, engineers in the aftermath of the September earthquake". ${ }^{104}$ The Commission stated that the type of structural analysis on the basis of the original design drawings were "not common" and that "of all the inspections we considered in evidence over the course of the Inquiry, $\mathrm{Mr}$ Coatsworth's was the most thorough". ${ }^{05}$

\subsubsection{Fatal Path Dependency: The Post-26 December 2010 Development}

When the aftershocks of Boxing Day 2010 (26 December) had happened a similar pattern of inspections evolved like the one after the earthquake of 4 September 2010. A Level 1 Rapid Assessment of the CTV building took place on 27 December again conducted by a team of CCC Building Inspectors to which belonged Marie Holland who held a bachelor's degree

\footnotetext{
${ }^{100}$ Royal Commission Vol. 6, 139.

${ }^{101}$ Royal Commission Vol. 6, 140.

${ }^{102}$ Ibid.

${ }^{103}$ Ibid.

${ }^{104}$ Royal Commission Vol. 6, 138.

${ }^{105}$ Ibid.
} 
in Architectural Design. ${ }^{106}$ In cross-examination before the Royal Commission, Ms. Holland had no recollection of the actual assessment of the CTV building and it remained uncertain whether it was actually her who had filled out the specific form sheet since the designation of the CTV building and the street address had been inserted in a different handwriting than hers. ${ }^{107}$ Ms. Holland had general knowledge about the nature of a Level 1 Rapid Assessment but had not conducted one so far. A team of the Urban Search and Rescue Service (USAR) also carried out an inspection. That team, however, completed only "a visual survey of the building from each direction". The team did not did discover any "obvious structural damage". ${ }^{108}$

Building manager Drew, apparently on his own initiative during the post-Christmas holiday season, tried to reach Mr. Coatsworth by telephone but to no avail. He made no further attempt to contact Coatsworth. ${ }^{109}$ However, now, for the first time, occupants of the CTV building were alarmed. ${ }^{110}$ The report of the Royal Commission mentions more than ten witnesses and their testimonies before the commission about visible additional damages after the Boxing Day earthquake with the exact location of the building, level by level. The main concerns of the occupants were visible cracks although some of them must already have existed before the 26 December earthquake.

One of the occupants, Ms. Jo-Ann Vivian, a manager of the tenant Relationship Services, called the CCC on 5 January 2011 with the request to arrange an inspection of the CTV building. According to the CCC computer record of her call, she referred to "a round structural pillar ... (which) has significant cracks in it". ${ }^{111}$ However, Vivian withdrew her request after a telephone conversation with Mr. Drew on 7 January 2011. According to the findings of the Royal Commission, Drew as the building manager did notice additional damage to the CTV building as a result of the Boxing Day earthquake but perceived and interpreted it as "limited to some more broken windows and some cracks that had widened". In crossexamination before the commission, he also referred to comments made by Mr. Coatsworth before the Boxing Day earthquake who, according to

\footnotetext{
${ }^{106}$ Royal Commission Vol. 6, 143.

${ }^{107}$ Ibid.

${ }^{108}$ Royal Commission Vol. 6, 145.

${ }^{109}$ Ibid.

${ }^{110}$ Royal Commission Vol. 6, 145-149.

${ }^{111}$ Royal Commission Vol. 6, 147.
} 
Mr. Drew, had predicted that cracks could widen as "just a normal part of the flexing" but that Coatsworth had "indicated that there was no concern basically". ${ }^{112}$ In accordance with this assessment, Drew made arrangements for the repair of the identified damages and representatives of a firm specialized in concrete repairs did inspect the CTV building in the first half of February 2011. ${ }^{113}$ Their preparations were still on their way when the earthquake of 22 February 2011 caused the CTV building to collapse. The Royal Commission maintained that it was Mr. Drew's omission not to ask Mr. Coatsworth to re-inspect the building who, after all, had the most intimate knowledge about the pre-existing damages from the 4 September 2010 earthquake. ${ }^{114}$ That Coatsworth, in the course of yet another inspection, would have conducted an analysis of the structural design of the building and potential damages to it is all but certain.

When the CTV building at 249 Madras Street in Christchurch collapsed during the earthquake on 22 February 2011, 115 people were killed and many others were injured. It goes to the credit of the Royal Commission that it devoted an entire chapter of the relevant volume of its report to those who had lost their lives.

\subsection{Case Analysis}

\subsubsection{Turning Points and Critical Junctures}

The findings of the Royal Commission left no reasonable doubt that there was one single core episode from which the causal chain originated that resulted in the collapse of the CTV building on 22 February 2011. It comprises the timespan between 26 August and 30 September 1986 when Graeme Tapper, the buildings engineer of the Christchurch City Council realized flaws in the submitted design of the building but ultimately issued the building permit anyway. The Royal Commission stated: "We conclude that the building permit should not have been issued". ${ }^{115}$ So the issuance of the permit can be identified as the critical juncture at which a causal process started that was not unstoppable but shaped by a very strong path dependency. As the Royal Commission confirmed, the structural design of

\footnotetext{
${ }^{112}$ Royal Commission Vol. 6, 149.

${ }^{113}$ Ibid.

${ }^{114}$ Royal Commission Vol. 6, 150.

${ }^{115}$ Royal Commission Vol. 6, 88 .
} 
the CTV building did not comply with the relevant legal requirements, especially not with those devoted to the protection against seismic forces. This applied specifically to the connections between the floors of the sixstory building and the north wall complex. ${ }^{116}$

According to the findings of the Royal Commission, the Christchurch City Council on 20 September 1986 issued a permit for the future CTV building that should never have been granted. The buildings engineer in charge at the time, Graeme Tapper, had asked the actual designer, David Harding of Alan M Reay Consulting Engineer (ARCE, later on Alan Reay Consultants Ltd. or ARCL), to submit detailed structural drawings calculations in support of the application for the building permit filed with the CCC on 17 July 1986. Tapper identified, according to the Royal Commission, "a significant structural issue in the design" of the building's architecture, specifically pertaining to the diaphragms connecting the floors of the six-story building to an extension with the stairwells, denoted in the drawings as the "north wall complex". Despite the fact that Tapper raised the issue with ARCE in a letter the design of these connections was not amended and despite this omission the building permit was issued on 30 September 1986. Prior to that, Alan Reay, the principal of ARCE, according to the findings of the Royal Commission "personally convinced" Tapper's superior, Bryan Bluck, that Tapper's concerns were unfounded whereupon Bluck instructed Tapper to sign off the design and to issue the permit. That moment marks the first and fundamental critical juncture. The alternative path was not fictitious but clearly available and it was the path Graeme Tapper as the buildings engineer of the CCC in charge would certainly have embarked on if not instructed otherwise.

Once taken, the wrong path turned out to be particularly strong in shaping the remaining sequences of decisions and omissions. Yet, it was not irreversible. What characterizes the tragedy of the ultimate collapse of the CTV building and the death of 115 people was, instead, that the path to disaster could have been suspended at at least three occasions. One was the retrofit of the diaphragms between the floors of the CTV building and the north wall complex and the long lasting phase of preparation that preceded it stretching from late January 1990 through October 1991. It culminated in the installation of three drag bars designed to strengthen the diaphragms, a measure taken without the required permit of the Christchurch City Council. Two more opportunities for intervention

\footnotetext{
${ }^{116}$ Royal Commission Vol. 6, 272.
} 
presented themselves after the earthquake of 4 September and the aftershocks of Boxing Day (26 December) 2010.

In January 1990, the Canterbury Regional Council (CRC) articulated its interest in purchasing the CTV building. The council engaged an engineering consultant, Holmes Consulting Group (HCG). Their engineer, John Hare, explicitly asked Bryan Bluck of the Christchurch City Council if the CCC had identified any "issues" during the building permit and construction process. Bluck did mention three issues none of which was related to the structure of the building and Hare had no drawings or calculations at his disposal. He nonetheless identified "a vital area of noncompliance with current design codes" when inspecting the CTV building. This and the implied repair costs caused the CRC to abandon the plan to purchase the CTV building which was subsequently acquired by the investment firm Madras Equities.

Significantly enough, the original designers, Alan Reay Consultants Ltd. (ARCL), were clearly aware of the very structural issues that made the Canterbury Regional Council refrain from acquiring the CTV building. After all, those problems had been discussed between ARCE/ARCL principal Alan Reay and CCC's chief buildings engineer Bryan Bluck when the review of the structural design was still underway in September 1986. It is also indicative that ARCL did not approach the new owner directly. Instead, ARCL's principal Alan Reay asked the firm's insurer whether informing the new owner of the CTV building was advisable given potential liability risks. In an extremely protracted process of deliberations and consultancy, Alan Reay and Geoffrey Banks of ARCL downplayed the issue and, in September 1991, came up with a plan to retrofit the diaphragms connecting the floors of the CTV building at the three upper levels in the form of steel drag bars to the north wall complex. These works were performed in October 1991 without the required CCC permit which was diagnosed by the Royal Commission as an act of noncompliance with the relevant legal stipulations. At any rate, no in-depth investigation into the nature of the design issues took place. Again, an opportunity to verify and to recalculate the soundness of the structural design of the building was missed. The responsibility clearly lay with those who were in possession of the original drawings and calculations, ARCL and Alan Reay in person. Reay, however, had an incentive to reduce liability risks while the Christchurch City Council as the neutral institution not exposed to such conflict of interest remained entirely uninvolved in this 
crucial episode precisely because ARCL failed to apply for a permit for the drag bar related retrofit works.

While it is difficult to define a critical juncture in the conventional sense when it comes to a protracted process of half-hearted inspections, deliberations and sometimes deliberately delayed decision making it is quite obvious that the decisive threshold was surpassed when, in September 1991, Alan Reay and Geoffrey Banks of ARCL decided to go ahead with retrofit works of limited scale and scope without seeking the statutory building permit.

The final sequence of tragic errors and fateful omissions started with the earthquake of 4 September 2010. This episode stretched over a relatively long period of time, until the last and disastrous earthquake of 22 February 2011. It started with the misguided so-called Level 2 Rapid Assessment performed on 7 September 2010 by three CCC inspectors none of whom was a trained engineer nor were they experienced with building inspections. The inspectors were acting under ambivalent written and oral instructions since, on the one hand, they were told by the responsible CCC official to request additional inspection by an engineer in case they deemed that necessary given the conditions of the CTV building. On the other hand, they found a green placard already in place that had been stuck to the building since the afternoon of 5 September when a so-called Level 1 Rapid Assessment had been performed. Unaware of the exact proceedings of the rapid assessments and their requirements, the inspectors were neither aware of the superficial character of a Level 1 Assessment nor of the exact implications of the wording of the green placard that recommended the engagement of an engineer by the owner of the building. After visual inspection of various parts of the building the inspectors just re-issued the green placard, a measure they were not entitled to take in the absence of an engineer. The building manager did nonetheless engage an engineer who inspected the building three times between 29 September and 19 October 2010. He confirmed that the building remained "structurally sound" but, at the same time, recommended further assessment. No such assessment was carried out, however.

So one may define 7 September 1990 the actual critical juncture since it was at that point that an inappropriate handling of the Level 2 Rapid Assessment paved the way to further neglect which with necessity remained connected to the plausible assumption that no fundamental structural design issue could have aggravated the impact of the earthquake. Under this very assumption, the psychological threshold to insist on a thorough 
structural analysis based on the original drawings and calculation of 1986 was high. Which applied also to David Coatsworth, a seasoned engineer, who carried out three additional inspections of the CTV building on behalf of the owner, Madras Equity.

Coatsworth remained the key figure, most likely without being aware of it, in the final part in the tragic series of cumulative errors and omissions that characterize the time span between the earthquakes of 26 December 2010 and 22 February 2011. It could have made a decisive difference if the building manager in charge, John Drew, would have been more insisting in his attempts to reach Coatsworth after the Boxing Day (26 December) earthquake. Coatsworth was at the time according to all evidence the best informed engineer around with intimate knowledge of the conditions of the CTV building except for an in-depth investigation into the structural design and potential issues. However, Drew made no further attempt to contact Coatsworth when a telephone call was to no avail. Drew's own trust in the stability of the CTV building was underlined by the fact that he moved into it with his family in early 2011 . He reacted accordingly when occupants approached him, being alarmed by cracks and gaps in walls and columns. One occupant had contacted the CCC directly with a request for an inspection of the building but withdrew it after a telephone conversation with Drew on 7 January 2011.

In sum, Drew's omission to consult Coatsworth, although committed in good faith, one more time followed the pattern of neglect and insufficient risk awareness. Yet, it can be classified a turning point at which an existing path dependency was accentuated rather than generating a new one. Drew initiated repairs whose preparation where still on their way when the CTV building collapsed on 22 February 2011 (Fig. 4.1).

\subsubsection{Contributing Factors and Necessary Conditions}

While there were clearly identifiable errors and omissions which, in principle, could have been easily avoided by the relevant key actors there were also persisting organizational and legal permissive conditions whose existence was of a more objective nature. Those conditions could and should have been taken into account by the relevant decision makers. Still, a considerable amount of blurred responsibilities could have been avoided in the first place.

One 'contributing factor' in this sense was the practice at the Christchurch City Council to start the review of applications for a building 


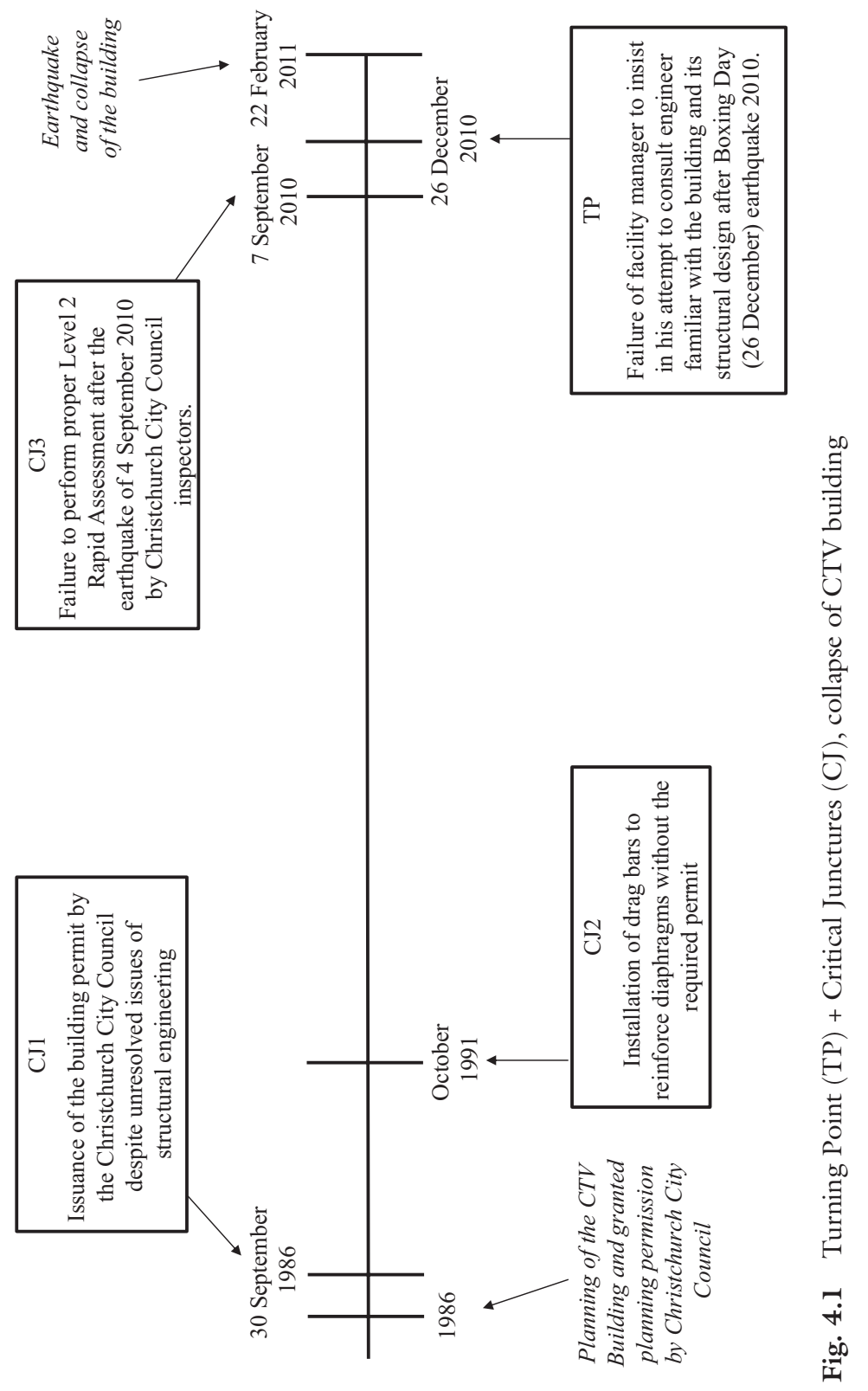


permit without complete documentation of the planned structural design of the envisaged structure. On the one hand, this was a plausible concession to applicants, typically design engineers working under pressure to get a project started. On the other hand, that pressure was likely to create counterincentives to diligent review. By their very nature, checking procedures and related calculations are particularly demanding while contractors and consultants typically act under time pressure. To start the review of applications for a building permit without complete documentation meant to compress the available time span for checking procedures even more once documentation was finally submitted. According to all evidence, this was exactly the situation the CCC's buildings engineer Graeme Tapper was facing when the structural drawings for the future CTV building were handed in to the CCC with a delay of 40 days after submission of the original application for the building permit. When Tapper, on the basis of additional documentation which still were incomplete due to missing calculations, articulated concerns about structural design issues his reluctance to sign off the design inevitably implied the risk of substantial delay of the entire project. Which in turn explains why Tapper's immediate superior, CCC's Chief Buildings Engineer Bryan Bluck, in a personal conversation with Alan Reay as the principal of ARCE as the applicant for the building permit, made the concession to have the permit issued without further scrutiny of the very design details that had raised the concerns of Graeme Tapper.

An implicit consequence of the established practice within the CCC was a creeping erosion of institutional integrity. This became apparent when in 1991 ARCL_-previously ARCE-designed the retrofit of the diaphragms connecting the floors of the CTV building to the north wall complex without seeking a related building permit. Significantly enough, this omission was justified in cross-examination before the Royal Commission by the principal of the firm, Alan Reay, with the remark that according to his experience Bryan Bluck as the Chief Buildings Engineer of the CCC would certainly have approved the envisaged procedure anyway. The arrogance aside, this clearly indicated the extent to which personal linkages of decision makers had replaced compliance with due diligence standards.

Another avoidable contributing factor that facilitated misunderstandings and outright errors committed after the first earthquake of 4 September 2010 were the guidelines for post-earthquake "rapid assessments". According to the traffic light system with green, yellow and red 
placards, a green placard entailed the explicit assurance that the building was sound and safe and no restrictions on use or occupancy were pronounced. At the same time, however, the wording on the very same placard "encouraged" the owners of the respective building "to obtain a detailed structural engineering assessment of the building as soon as possible". So neither was a detailed structural engineering assessment performed by the CCC itself on a standardized basis nor was it made a compulsory duty of the owner of a building. Specifications of a "detailed structural engineering assessment" did not exist either. The absence of such binding prescriptions made it possible that a seasoned engineer, Geoffrey Coatsworth, engaged by the owner after the 4 September earthquake, did indeed perform a structural engineering assessment but confined himself to do that without the relevant documentation which, in turn, was in possession of the CCC.

Yet, however insufficient and risk increasing these contributing factors were, their undesirable effect could have been neutralized with minor efforts. This is particularly striking with respect to the root cause of the entire tragedy, the building permit that according to the judgment of the Royal Commission should never have been issued.

It is beyond reasonable doubt that without the intervention of Bryan Bluck in his capacity as chief buildings engineer of the Christchurch City Council in favor of a prompt issuance of the permit a thorough and diligent review of the structural design of the building and a verification of the related calculations would have been performed. It is also extremely likely that in the course of such scrutiny the crucial design errors would have been detected. To renounce on a structural analysis and related calculations of the building's design can therefore be defined as the basic necessary condition of the ultimate disaster to occur.

Another barely disputable necessary condition is the failure to perform a proper Level 2 Rapid Assessment after the earthquake of 4 September 2010. This assessment would have required the compulsory engagement of a trained engineer but it was performed on 7 September 2010 without one. The definition of this omission as a necessary condition depends admittedly on the assumption that a "detailed structure engineering assessment of the building" as recommended in the wording of the green placard would have included a re-analysis of the structural design of the CTV building based on CCC documentation and independent calculations. The validity of this assumption is underlined by the fact that the experienced engineer, David Coatsworth, who was indeed engaged by the 
owner of the CTV building initially requested the relevant CCC documentation but did not insist on his request when CCC declared that handing over the documents, including the structural drawings and calculations, would take several weeks under the given circumstances. On the other hand, the building manager John Drew did not notify Coatsworth when the CCC documentation including the structural drawings turned out to be available earlier than expected. So, as far as the recommendations of the wording on the green placard were concerned, both Drew and Coatsworth had the right impulse to initiate and to conduct "a detailed structural engineering assessment of the building" but in the end they did not act accordingly. The same applies to the failure of building manager Drew to follow with sufficient resolve his own impulse to have Mr. Coatsworth return to the damaged CTV building for a structural engineering assessment after the Boxing Day earthquake of 26 December 2010.

There was ultimately no single sufficient condition for the collapse of the CTV building to occur. What emerged was a quite typical pattern of jointly sufficient necessary conditions that themselves were embedded in permissive conditions whose common denominator was diffused responsibility and diluted professional standards. Which brings us to a more detailed analysis of the identifiable causal mechanisms and their more or less exemplary nature (Table 4.1).

Table 4.1 Contributing Factors (CF) and Necessary Conditions (NC), collapse of CTV building

CF1 Tolerated practice to submit applications for building permits to the Christchurch City Council without supporting documentation at the date of submission.

$\mathrm{NCl}$ Issuance of the building permit by the Christchurch City Council despite unresolved issues of structural engineering, 30 September 1986.

CF2 Imprecise Christchurch City Council guidelines for post-earthquake Rapid Assessments.

NC2 Installation of drag bars to reinforce diaphragms without the required permit of the Christchurch City Council, October 1991.

NC3 Failure to perform proper Level 2 Rapid Assessment after the earthquake of 4 September 2010 by Christchurch City Council inspectors.

CF3 Failure of facility manager to insist in his attempts to consult engineer familiar with the building and its structural design after the Boxing Day (26 December) earthquake 2010. 


\subsubsection{Causal Mechanisms}

The three main episodes resulting in the collapse of the CTV building on 22 February 2011 had a common substantive core. Each time, a thorough and diligent structural engineering assessment was at stake and each time it did not take place. This applies to the structural checking of the application for the building permit in 1986, the retrofit works of 1991 and the inspection of the damages to the building after the earthquake of 4 September 2010. What is more, the omission of a sound structural engineering assessment at three different occasions reveals a common pathological core in the form of almost identical causal mechanisms of an exemplary nature. "Exemplary" means that the mechanisms are typical for the institutional and professional environment in which they occurred. Therefore, their existence and risk increasing potential is known in principle. Moreover, because that is so the undesirable effects of those mechanisms are usually kept under control unless additional mechanisms suspend precisely that control. Accordingly, there is a high level of observable regularity when it comes to system-specific causal mechanisms, antidotes and the forces that might neutralize those antidotes. Hence, here again, the prospects of generalization for the sake of learning and prevention.

When it comes to the relevant permissive conditions in the form of situational mechanisms, it was a characteristic arrangement that blurred accountability and paved the way to the acceptance of diluted professional standards. ${ }^{17}$ This affects the relationship between the relevant public authority with jurisdiction over building and issuing building permits on the one hand and applicants for building permits on the other hand. In the case of larger buildings or complex construction projects the applicant is typically a consultancy firm or major contractor. What matters are clearcut jurisdictional boundaries that guarantee that both parts do justice to their professional obligations and to the institutional logic those obligations belong to. These boundaries were systematically blurred in the relationship between the Christchurch City Council (CCC) and the consultancy firm Alan Reay Consultancy Engineers/Consultancy Ltd. (ARCE/ARCL) as "Professional Designer" and key-consultant. While it was plausible policy of the CCC to process requests for building permits expeditiously given the economic importance of construction and the

${ }^{117}$ Johan P. Olsen: Accountability and Ambiguity. In Mark Bovens, Robert E. Goodin, and Thomas Schillemans, eds.: The Oxford Handbook of Public Accountability. Oxford: Oxford University Press 2014, 106-123. 
overall requirements of service orientation one consequence was tolerance and concessions toward incomplete applications and late submission of documentation, especially structural drawings and related calculations. This gave contractors and consultants leverage over the CCC since late submission of sophisticated structural drawings and related calculations meant that the envisaged date of construction works to begin was approaching and, accordingly, the CCC was under pressure not to delay their start.

What emerged was a latent hybridity of public and private functions and ambiguous role patterns. ${ }^{118}$ In the essence, the relationship between the CCC and larger consultants or constructors as applicants for a building permit were structurally asymmetric. Instead of the CCC being literally the authority enforcing the relevant legal stipulations even against reluctance of the applicants for a building permit-after all, the conventional model of serving the public interest-it was the applicants who were enabled to exert mild pressure on the CCC, even at the expense of due diligence in the process of structural engineering assessment as a typically tedious and time consuming task relevant authorities have to assume. Those were more or less the situational mechanisms to which the CCC was exposed in any larger process of structural checking and preparation of a building permit.

These conditions created a particular incentive structure at the level of the action formation mechanisms. In the essence, those incentives undermined the professional integrity of the civil engineers who worked with the Christchurch City Council as the building authority ${ }^{119}$ a creeping erosion of professional integrity ${ }^{120}$ that has been denoted as "normalization of deviance". ${ }^{121}$ The pre-history of the collapse of the CTV building may indeed be categorized as the classic example of misguided

${ }^{118}$ For latent hybridity, its functions and dysfunctions, cf. Wolfgang Seibel: Studying Hybrids. Sectors and Mechanisms. Organization Studies 36 (2015): 697-712.

${ }^{119} \mathrm{cf}$. Philip Selznick: Leadership in Administration. A Sociological Interpretation. Berkeley and Los Angeles: University of California Press 1957, 118-133, as a classic description of the necessity to defend professional and institutional integrity.

${ }^{120}$ For slow institutional decay see the classic study by Samuel P. Huntington: The Marasmus of the ICC: The Commission, the Railroads, and the Public Interest. The Yale Law Journal 61 (1952): 467-509.

${ }^{121}$ Diane Vaughan: The Dark Side of Organizations: Mistake, Misconduct, and Disaster. Annual Review of Sociology 25 (1999): 271-305; Diane Vaughan: The Challenger Launch Decision: Risky Technology, Culture and Deviance at NASA. 2nd ed., Chicago and London: The University of Chicago Press 2016. 
taken-for-grantedness and its fatal consequences. Once the negligent handling of structural engineering issues was accepted inside the Christchurch City Council it became common practice. That practice, in turn, undermined the sense for case-specific uniqueness and the necessity to inspect the peculiarities of a particular structural design of a building and potential non-compliance with the relevant regulatory framework.

The strength of those detrimental psychological forces is underlined by the fact that they made even seasoned professionals ignore existing regulation. Moreover, the resulting institutional softness of the CCC was apparently anticipated by consultants and contractors. They knew that they could afford not to comply with formal requirements even when issues of structural engineering were at stake. This is demonstrated, inter alia, by the fact that ARCL did not seek the compulsory building permit when planning and designing the retrofit of diaphragms of the CTV building in 1991 and that that omission was justified by the company's principal with the remark that he took it for granted that the CCC's chief buildings engineer would have granted the permit anyway.

By the same token, the stabilized culture of neglect was complemented by essentially misplaced trust. Not surprisingly, the illusion of institutional integrity persisted so that both laypeople and professional engineers with only occasional contact with the CCC took it for granted that the indispensable and, basically, standardized procedures of structural checking of a building's design had been performed. The discrepancy between the latent erosion of professional standards and integrity on the one hand and persisting public trust on the other hand is comforting and disturbing at the same time. It obviously did not occur to David Coatsworth, the civil engineer engaged by the owner of the CTV building after the September earthquake of 2010, that a sound structural engineering assessment of the building had never been performed. And it probably never occurred to the building manager John Drew that the trust he and Coatsworth invested in the professional skill and integrity of the Christchurch City Council was unfounded.

It is, accordingly, a reasonable question if the distinction between situational and transformational mechanisms makes sense at all when applied to the CTV building case. It is, indeed, hard to imagine that the distinctly strong path dependency of the overall neglect of structural engineering issues and misguided trust could have been suspended at any moment in time. Yet, the answer is a principle Yes. The transformational mechanism 
was the absence of leadership and resolve. ${ }^{122}$ Not that at a particular point of a disastrous causal chain a single actor could have intervened and did not do so. It was, rather, a creeping crisis ${ }^{123}$ of leadership especially at the helm of the responsible division of the Christchurch City Council that decisively contributed to both the "normalization of deviance" from regular professional standards of structural engineering assessment and the CCC's inability to address properly the post-earthquake situation of September 2010. Judgment and resolve would have been necessary after the earthquake of 4 September 2010 for the adequate management of building inspections. Instead, it was left to the discretion of private owners whether or not to engage an engineer for a sound structural engineering assessment. Sloppiness in handling structural engineering checking procedures and their documentation could and should have been recognized by the relevant CCC officials in the first place. What is more, however, a sound sense of responsibility beyond formal accountability standards ${ }^{124}$ should have ensured that standard operating procedures and routinized attitudes of staff had no detrimental effect on handling sensitive cases of structural engineering assessment in an earthquake prone environment. It was this particular quality of leadership that was tragically missing (Fig. 4.2).

${ }^{122}$ Cf. Paul 't Hart and Lars Tummers: Understanding Public Leadership. 2nd ed., London: Red Globe Press 2019, 50-51.

${ }^{123}$ Arjen Boin, Magnus Ekengren, and Mark Rhinard: Hiding in Plain Sight: Conceptualizing the Creeping Crisis. Risk, Hazards \& Crisis in Public Policy 11 (2020): 116-138. The literature on "creeping crises", mainly stimulated by the research of Arjen Boin et al., focuses on unresolved societal, economic or political problems. The phenomenon described in this chapter, however, refers to a "creeping" institutional crisis, "hidden in plain sight" as being addressed in Diana Vaughan's work on phenomena of "normalization of deviance" and analyzed in a classic version as institutional "marasmus" by Samuel P. Huntington back in 1952 ("The Marasmus of the ICC: The Commission, the Railroads, and the Public Interest", as quoted above).

${ }^{124}$ Carl J. Friedrich: Public Policy and the Nature of Administrative Responsibility. Public Policy 1(1) (1940): 1-20; Mark Bovens: The quest for responsibility: Accountability and citizenship in complex organizations. Cambridge: Cambridge University Press 1998. 


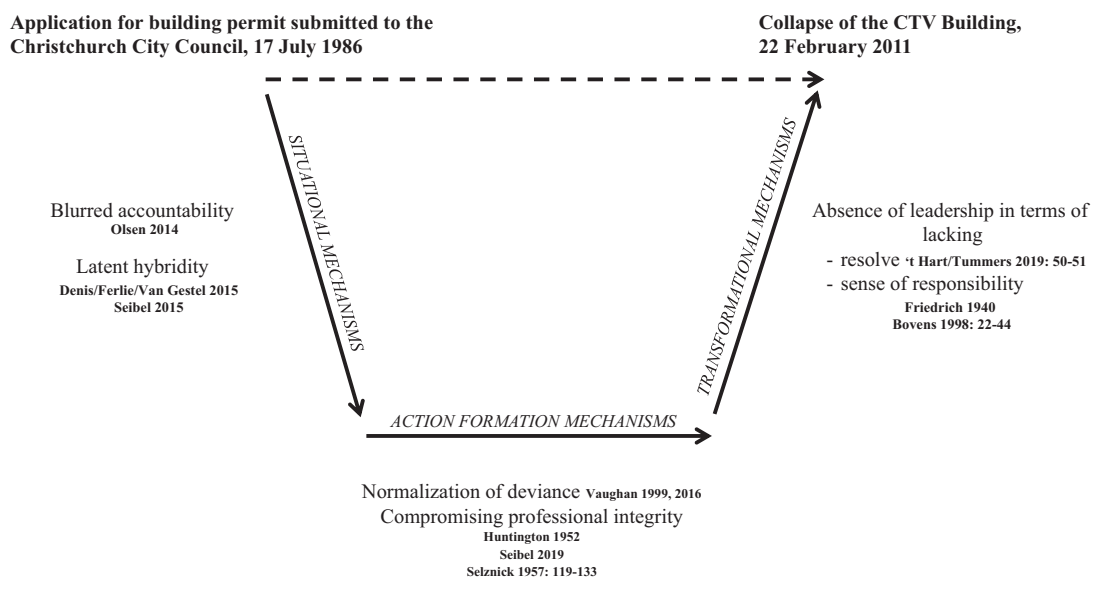

Fig. 4.2 Causal Mechanisms, collapse of CTV building

Open Access This chapter is licensed under the terms of the Creative Commons Attribution 4.0 International License (http://creativecommons.org/licenses/ by $/ 4.0 /$ ), which permits use, sharing, adaptation, distribution and reproduction in any medium or format, as long as you give appropriate credit to the original author(s) and the source, provide a link to the Creative Commons licence and indicate if changes were made.

The images or other third party material in this chapter are included in the chapter's Creative Commons licence, unless indicated otherwise in a credit line to the material. If material is not included in the chapter's Creative Commons licence and your intended use is not permitted by statutory regulation or exceeds the permitted use, you will need to obtain permission directly from the copyright holder.

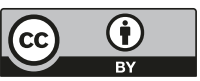

